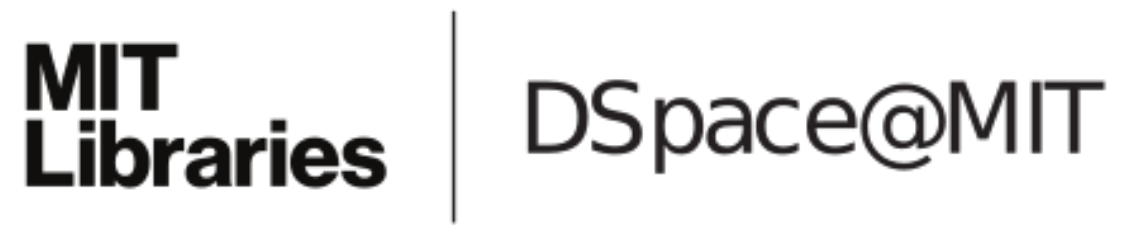

\author{
MIT Open Access Articles
}

Financial Reporting Quality, Private Information, Monitoring, and the Lease-versus-Buy Decision

The MIT Faculty has made this article openly available. Please share how this access benefits you. Your story matters.

Citation: Beatty, Anne, Scott Liao, and Joseph Weber. “Financial Reporting Quality, Private Information, Monitoring, and the Lease-versus-Buy Decision.” The Accounting Review 85.4 (2010): 1215-1238.

As Published: http://dx.doi.org/10.2308/accr.2010.85.4.1215

Publisher: American Accounting Association

Persistent URL: http://hdl.handle.net/1721.1/76295

Version: Author's final manuscript: final author's manuscript post peer review, without publisher's formatting or copy editing

Terms of use: Creative Commons Attribution-Noncommercial-Share Alike 3.0 


\title{
Financial Reporting Quality, Private Information, Monitoring and the Lease-versus-Buy Decision
}

\author{
Anne Beatty \\ beatty.86@osu.edu, 614-292-5418 \\ Fisher College of Business \\ The Ohio State University \\ 442 Fisher Hall \\ 2100 Neil Avenue \\ Columbus, OH 43210 \\ Scott Liao \\ scott.liao@rotman.utoronto.ca, 416-946-8599 \\ Rotman School of Management \\ University of Toronto \\ 105 St. George Street, \\ Toronto, ON M5S 3E6 \\ Joseph Weber \\ jpweber@mit.edu, 617-253-4310 \\ Sloan School of Management \\ Massachusetts Institute of Technology \\ 50 Memorial Drive, E52-325 \\ Cambridge, MA 02142
}

June 21, 2009

We would like to thank Wayne Thomas and two anonymous reviewers for many helpful suggestions that have resulted in substantial improvements to the paper. 


\begin{abstract}
A flourishing research stream examining how accounting quality affects asset purchases ignores off-balance sheet leasing. This research concludes that low accounting quality limits firms' access to capital for investments. Our finding that low accounting quality firms lease more of their assets has important implications for interpreting this research. Although low accounting quality firms may purchase fewer assets, our results suggest that these firms may substitute leased assets for purchased assets. To verify that leasing does not merely reflect these firms' desire for off-balance sheet accounting but instead substitutes for accounting quality when addressing agency problems, we investigate how banks' private information and monitoring affect the relation between accounting quality and leasing. We find a lower association between accounting quality and leasing when banks' have higher monitoring incentives and when loans contain capital expenditure provisions. The mitigation of the negative relation between accounting quality and leasing by other information asymmetry and agency cost reducing mechanisms suggests that this association reflects the role of accounting quality in reducing information problems. These findings also document cross-sectional variation in accounting quality's affect on leasing. Our paper suggests that ignoring the substitution between leasing and asset purchases affects the inferences from prior research.
\end{abstract}

Keywords: financial reporting quality; private information; monitoring; lease-versusbuy

Data Availability: Data are available from sources identified in the text. 


\section{INTRODUCTION}

A growing body of accounting research concludes that higher financial reporting quality reduces the negative effects of financing constraints on investment by mitigating information asymmetry (e.g. Biddle, Hilary, and Verdi, 2009, Lara, Osma, and Penalva, 2009, Biddle and Hilary, 2006, Verdi, 2006, Bushman, Piotroski and Smith, 2006, Hope, Thomas, and Vyas, 2009). This research generally focuses on asset purchases without considering alternative investment mechanisms, like leases that account for about a third of new equipment investment for U.S. firms. ${ }^{1}$ This oversight seems especially important since both Eisfeldt and Rampini (2008) and Sharpe and Nguyen (1995) find that firms facing greater financing constraints have a higher propensity to make off-balance sheet lease investments. Specifically, failing to consider the substitution between leasing and buying is likely to affect the inferences drawn from research examining the association between financial reporting quality and investment.

We extend this research by considering the role of accounting quality in the firm's propensity to lease assets (i.e. the proportion of assets that the firm leases). Both Sharpe and Nguyen (1995) and Eisfeldt and Rampini (2008) argue that leases provide creditors with more security, higher priority in bankruptcy, and an effective way of reducing adverse selection and moral hazard problems that arise from information asymmetries. Consistent with these arguments, they find that firms facing financing constraints, due to information asymmetries, are more likely to lease than purchase assets. In a related research stream, Verdi (2006), Biddle and Hilary (2006), Biddle et al. (2009), and Lara et

\footnotetext{
${ }^{1}$ Hope et al. (2009) investigate the intermediate step of whether accounting quality (transparency) affects firms' ability to gain access to financing.
} 
al. (2009) find that financial reporting quality alleviates the dampening effect of financial constraints on asset purchases by reducing information asymmetries. We combine these two research streams, arguing that low accounting quality firms facing larger financing constraints due to greater information asymmetries will have a greater propensity to lease assets.

To test this hypothesis we use a comprehensive sample of 3,033 manufacturing firms on the COMPUSTAT database. Our focus on manufacturing firms is consistent with previous research examining how financial constraints affect asset purchases. In addition, focusing on a single industry reduces concerns that industry induced correlations between leasing, financing, and accounting drive our results. ${ }^{2}$

We focus on the determinants of firms' propensities to use operating leases to acquire assets. We measure the firms' propensity to lease by dividing the capitalized minimum operating lease payment by the sum of that amount and the amount of Property, Plant, and Equipment (PP\&E). By capitalizing operating leases, the measure is unlikely to be affected by the differences in accounting treatment for leased versus purchased assets. To proxy for our primary variable of interest, financial reporting quality, we follow Bharath et al. (2008) by using the first principal component of three accrual-based accounting quality metrics. ${ }^{3}$ In our regressions, we also control for size, tax incentives, financing constraints, and other factors expected to affect leasing decisions.

\footnotetext{
${ }^{2}$ The statistical significance of the coefficients on our variables of interest is not sensitive to this choice.

${ }^{3}$ As discussed in Appendix A, the three measures are Teoh, Welch, and Wong's (1998) absolute value of current discretionary accruals, Dechow, Sloan and Sweeney's (1995) absolute value of total discretionary accruals, and the cross-sectional version of Dechow and Dichev's (2002) absolute value of current discretionary accruals.
} 
We find that firms with worse financial reporting quality have a greater propensity to lease their assets. This result highlights the importance of considering leasing when studying the effects of financial reporting quality on investments. Without considering the leasing alternative, the existing research concludes that firms with poor accounting quality have financial constraints, inhibiting their ability to invest. Although low accounting quality firms may purchase fewer assets due to financial constraints, our results suggest that these firms may substitute leased assets for purchased assets. One interpretation of our finding that poor accounting quality firms lease more of their assets is that these firms substitute lease financing for other forms of secured borrowing. An alternative explanation for our finding is that the negative association between the proportion of assets leased and accounting quality merely reflects the desire of low accounting quality firms to engage in off-balance sheet financing.

To distinguish between these alternatives, we investigate how other mechanisms that reduce information asymmetry and agency problems impact the relationship between accounting quality and leasing propensity. Specifically, we investigate how lenders' monitoring and loan covenants affect the association between accounting quality and leasing propensity. If the association between accounting quality and leasing reflects the role of accounting quality in reducing information asymmetry, then we would expect the negative relation between accounting quality and leasing to be mitigated by other information asymmetry and agency cost reducing mechanisms, suggesting that accounting quality and leasing are alternative ways to address financial constraints. Alternatively, if off-balance sheet accounting motivates firms with poor accounting 
quality to lease, then the relationship between leasing and accounting quality should not be affected by other information asymmetry reducing mechanisms.

In addition, this analysis allows us to extend Biddle and Hilary's (2006) investigation of whether cross-sectional differences in access and use of private information and monitoring affect the role of accounting quality in investment decisions. Specifically, Biddle and Hilary (2006) suggest that the role of accounting quality in capital investment decisions depends on the firm's use of other monitoring mechanisms that reduce information asymmetry. We expand this conjecture, suggesting that both the quality of banks' monitoring and the covenants banks use to restrict investment will affect the importance of accounting quality in the lease-versus-buy decision.

To test these hypotheses we use a sub-sample of manufacturing firms with syndicated bank loan data on either the Loan Pricing Corporation (LPC) or Security Data Corporation (SDC) databases. There are two primary reasons why we focus on this important sub-sample of the debt market. ${ }^{4}$ First, the variation in bank loan ownership provides cross-sectional variation in lenders' monitoring incentives. Lead lenders with proper financial incentives to conduct due diligence reviews prior to loan initiation and to provide loan monitoring over the life of the contract have incentives to reduce the agency problems induced by information asymmetries between lenders and opaque borrowers. Therefore, we hypothesize that when lead lenders have greater due diligence and monitoring incentives, the importance of the quality of accounting information in the lease-versus-buy decision will be mitigated.

\footnotetext{
${ }^{4}$ Sufi (2007) reports that syndicated loans represent $51 \%$ of U.S. corporate finance originations, and generates more underwriting fees than both equity and debt underwriting. He also notes that almost $90 \%$ of the largest 500 non-financial COMPUSTAT firms obtained a syndicated loan between 1994 and 2002.
} 
The second advantage of focusing on syndicated loans is that, unlike public debt, there is cross-sectional variation in the use of contractual limitations on asset purchases in these loans. ${ }^{5}$ When a firm's debt contract contains an investment restriction covenant designed to mitigate the agency problems of debt, we expect the quality of accounting information will be less important in controlling information problems. Accordingly, we hypothesize that the effect of accounting quality in the lease-versus-buy decision decreases in the face of investment restriction covenants.

We identify a sub-sample of 997 manufacturing firms with loan ownership data in the LPC database to test our predictions about the effects of banks' direct and indirect monitoring on the role of accounting quality in the lease-versus-buy decision. Based on Sufi (2007) and Ball, Bushman and Vasvari (2007) we use lead lender ownership to proxy for lenders' due diligence and monitoring incentives. ${ }^{6}$ Consistent with bank monitoring substituting for accounting information, we find that accounting quality is less important in the lease-versus-buy decision when lead lenders' ownership is high. ${ }^{7}$

We then examine the effects of contractual restrictions on asset purchases using a subsample of 865 manufacturing firms with information on the investment restriction covenant in the SDC database. We use an indicator variable to capture the effects of covenants on leasing decisions. Consistent with our previous analysis, we find that the magnitude of the correlation between our accounting quality measure and proportion of

\footnotetext{
${ }^{5}$ Nini, Smith, and Sufi (2007) find that $32 \%$ of U.S. bank loans contain this covenant, while we find that less than 5\% of public debt uses this covenant to directly restrict firms' opportunistic investments.

${ }^{6}$ In sensitivity tests, Sufi (2007) documents that the lead lender ownership measure is very robust.

${ }^{7}$ The results on tests of the monitoring hypothesis and the investment restriction hypothesis are both robust to controls for self-selection. In particular, we employ an endogenous switching model that controls for the endogeneity of the choice to have high lender monitoring, or the inclusion of an investment restriction.
} 
assets leased is lower in the presence of this covenant, suggesting that this covenant diminishes the importance of accounting information in the lease-versus-buy decision.

Our results are robust to a variety of different research design choices. Specifically, we examine the sensitivity of our results to limiting our sample to manufacturing firms and to our choice of measures for leasing propensity, accounting quality, and lead lender measures. We also investigate the sensitivity or our results to the methods we use to address endogeneity concerns, and the methods we use to address firms with missing lease data. Finally, we also investigate whether our results are affected when use an alternative research design to address cross-sectional variation in financing constraints. Our results are insensitive to each of these research design modifications.

Our paper contributes to the accounting literature examining the role of accounting quality in investment decisions, and to the finance literature examining the determinants of the decision to lease-versus-buy assets. Our results indicate that firms with information asymmetries due to poor accounting quality are more likely to lease their assets. These findings suggest that ignoring the use of off-balance sheet leasing as a substitute for asset purchases is likely to affect the inferences about firms' investment policies that can be drawn from the existing research examining the association between accounting quality and asset purchases. Our results also suggest that accounting quality is important in mitigating the financing constraints that lead firms to lease rather than buy assets.

Our setting also allows us to test the conjecture made in previous research that banks' use of covenants, access to private information and monitoring are substitutes for accounting information in reducing information asymmetries. Our results suggest that 
bank monitoring and covenant restrictions are substitutes for accounting quality's influence on investment decisions.

The rest of the paper is organized as follows: Section 2 provides the background to our study, Section 3 contains the hypothesis development, Section 4 discusses the sample selection and database, Section 5 displays the model specification, empirical results are presented in Section 6, robustness checks are reported in Section 7, and conclusions are drawn in Section 8.

\section{BACKGROUND}

\section{Information Asymmetry and Investment}

Fazzari, Hubbard, and Petersen (1988) examine the importance of capital market imperfections caused by information asymmetry between managers and outside capital providers on firm optimal investment decisions. They find that financially constrained firms rely on internally generated cash flows to fund their investments, increasing the sensitivity of their investments to cash flows. ${ }^{8}$

Bushman et al. (2005), Hope et al. (2009), Biddle and Hilary (2006), Verdi (2006), Biddle et al. (2009), and Lara et al. (2009) suggest that aspects of the firms' accounting reports may affect the extent to which firm's information asymmetry problems affect their investments. When accounting quality is high, information asymmetry is expected to be low, reducing the sensitivity of investment to cash flows (or increasing the firm's ability to make investments).

\footnotetext{
${ }^{8}$ Although many studies conclude that information asymmetry and financing constraints decrease investment efficiency, some argue that it is inappropriate to use investment-cash flow sensitivity to proxy for investment efficiency (e.g., Kaplan and Zingales, 1997, 2000, and Bushman, Smith and Zhang, 2007).
} 
Using timely loss recognition as a measure of accounting quality, Bushman et al. (2005) investigate cross-country variation in the timeliness of loss recognition and the timeliness of change in investment policy. They find that firms in countries with more timely loss recognition respond more quickly to declining investment opportunities by reducing net inflows of capital to new investments. Their paper implies that better accounting quality leads to increased investment efficiency.

Hope et al. (2009) investigate the relationship between financial reporting transparency and firm's ability to access capital. They identify a sample of privately held firms with cross-sectional variation in whether an audit has been conducted, and find that audited firms with more transparent financial statements have better access to external finance. Their results imply that financial transparency influences information asymmetries, and thus influence firm's access to capital from traditional debt markets.

Biddle and Hilary (2006) examine how accounting quality affects firms' investment-cash flow sensitivity. They examine the effect of accounting quality on shocks to investment. They find that higher accounting quality is associated with lower investment-cash flow sensitivity. They also find that accounting quality plays a relatively more important role in economies where the capital is primarily provided through arm'slength transactions and investors do not have access to private information. At the extreme, Biddle and Hilary (2006) find that in Japan, where capital is typically provided by keiretsu and banks, accounting quality does not affect the association between investment and cash flows. One of the implications of Biddle and Hilary's (2006) results is that firms with poor accounting quality are more likely to rely on internally generated cash flows to fund their investments, and thus they have more difficulty obtaining 
external financing to fund their investments. Their results also imply that the role of accounting quality in capital investment decisions depends on whether the firm uses other monitoring mechanisms that reduce information asymmetry.

Verdi (2006), and Biddle et al. (2009) are concerned with both whether firms overinvest in losing projects and with whether they under-invest in positive net-present-value projects. Both Verdi (2006) and Biddle et al. (2009) find that financial reporting quality is positively correlated with investment when firms are prone to under-invest and is negatively correlated with investment when firms are prone to over-invest. They conclude that, "higher quality financial reporting enhances investment efficiency (for both capital and non-capital investment) by helping to mitigate both over- and underinvestment." Lara et al. (2009), have a similar study and draw similar conclusions, but use an alternative measure of accounting quality.

These studies focus on the role of accounting quality on either firms decisions to purchase assets (like PP\&E) or their ability to obtain traditional financing, (like debt or equity). ${ }^{9}$ The results imply that firms with poor accounting quality have difficulty raising capital from either debt or equity markets, and thus invest sub-optimally. Thus firms with lower quality accounting are inefficient (have lower investment efficiency). In this paper, we extend this research by investigating whether firms with lower quality accounting are precluded from investment, or whether they can invest in assets through an alternative form of financing (an operating lease).

\footnotetext{
${ }^{9}$ The choice to study the effects of financing constraints on investment in assets on the balance sheet (like PP\&E) is not unique to these papers. Most of the finance research in this area follows this same approach.
} 


\section{Leasing and Financing Constraints}

Eisfeldt and Rampini (2008) and Sharpe and Nguyen (1995) find that firms with larger information asymmetries (greater financing constraints) are more likely to obtain their assets through leases. Sharpe and Nguyen (1995) suggest that institutional features specific to operating leases provide lessors with important advantages in bankruptcy. ${ }^{10}$ If the lessee goes bankrupt, the lessee can either accept or breach all lease obligations. If the lessee accepts the obligations, the lessor is entitled to continue receiving payments based on the original lease agreement. The rental expenses, along with lessors' other claims, are classified as administrative expenses in the bankruptcy code, which must be paid immediately or 'within a reasonable period'. ${ }^{11}$ In this case, the bankruptcy filing does not change the status of the lessor's claims. Alternatively, if the lessee breaches the lease obligations, then the lessor can immediately repossess the property. Any economic losses accompanied with this repossession, including unpaid rents, late fees, or the loss regarding the re-lease or sale of the property is an unsecured claim against the lessee. In contrast, other creditors are left with no assurance that their claims will be recovered. ${ }^{12}$

Sharpe and Nguyen (1995) argue that the preferential treatment of leases in bankruptcy causes financially constrained firms to prefer to lease assets rather than borrow to buy assets. Consistent with this prediction they find that firms that are nondividend-paying, lower-rated, or cash-poor are more inclined to use operating leases than

\footnotetext{
${ }^{10}$ SFAS No. 13 requires leases to be classified as either operating or capital. A lease meeting any of the following four criteria is classified as a capital lease: (1) ownership of the leased asset is transferred to the lessee at lease maturity, (2) a bargain purchase option is available, (3) the lease term is equal to $75 \%$ or more of the remaining economic life of the leased asset, and (4) the present value of the minimum lease payments equals or exceeds $90 \%$ of the asset's market value.

${ }^{11}$ Lessors' other claims might include, but not limited to, delinquencies, late fees, and other damages suffered.

${ }^{12}$ This provision applies to operating leases, but not capital leases. If the original lease contract stipulates that the lessor does not retain property ownership at lease maturity, then the lease is treated as secured debt.
} 
non-financially constrained firms. This suggests that firms with information asymmetries due to poor accounting quality may have other alternatives, like leasing, to fund their investments.

\section{Banks' Private Information and Monitoring}

Biddle and Hilary (2006) suggest that there are other mechanisms that may substitute for accounting quality in reducing information asymmetry thereby alleviating financing restrictions and thus increasing investment efficiency. In contrast to their findings for the U.S., Biddle and Hilary (2006) find that investment-cash flow sensitivities do not vary with accounting quality in Japan. They conjecture that, unlike U.S. markets, Japanese capital markets resolve information asymmetry problems through relationship banking and thereby public information loses its importance in affecting firm operations. Biddle and Hilary (2006) argue that banks' superior private information should serve as a substitute for accounting quality in determining the sensitivity of investment to internally generated cash flows. ${ }^{13}$

In addition to having access to private information, Nini et al. (2006) suggest that bank loan contracts often include covenants setting an upper limit on capital expenditures and find that this capital expenditure restriction provision successfully reduces firms' capital expenditures. They argue that the investment restriction covenant mitigates the asset substitution and overinvestment problems. Typically, in these covenants, capital expenditures are defined as assets included in the property, plant and equipment accounts under GAAP. Therefore, the covenants would restrict asset purchases and capital leases,

\footnotetext{
${ }^{13}$ This prediction is consistent with theoretical models such as Holthausen and Verrecchia (1998)
} 
but not operating leases, and thus are likely to affect both the use of operating leases, and the importance of accounting information in the leasing decision.

The following excerpt from Georgia Pacific's December 2005 syndicated loan agreement is an illustration of a typical capital expenditure restriction:

FINANCIAL COVENANTS

Maximum Capital Expenditures of up to:

$\begin{array}{lr}\text { Fiscal Year } & \text { Capital Expenditures } \\ 2006 & \$ 900,000,000 \\ 2007 & \$ 1,100,000,000 \\ 2008 & \$ 1,100,000,000 \\ 2009 & \$ 900,000,000 \\ 2010 \text { and thereafter } & \$ 700,000,000\end{array}$

The lesser of (a) $100 \%$ of the unused amounts allocated to any year and (b) $50 \%$ of the maximum Capital Expenditures permitted in such year shall be available for Capital Expenditures in the following fiscal year only. In addition, the Capital Expenditure covenant will permit the amount permitted, but not used, for Restricted Payments and investments in joint ventures under clause (12) of the definition of "Permitted Investments" to be used to make additional Capital Expenditures. Capital Expenditures shall exclude, whether or not such a designation would be in conformity with GAAP, expenditures made in connection with the replacement or restoration of property, to the extent reimbursed or financed from insurance or condemnation proceeds.

\section{CERTAIN DEFINITIONS}

"Capital Expenditures" means, for any period and with respect to any Person, any and all expenditures made by the Parent or any of its Subsidiaries in such period for assets added to or reflected in its property, plant and equipment accounts or other similar capital asset accounts or comparable items or any other capital expenditures that are, or should be, set forth as "additions to plant, property and equipment" on the consolidated financial statements of the Parent prepared in accordance with GAAP, whether such asset is purchased for cash or financed as an account payable or by the incurrence of Indebtedness, accrued as a liability or otherwise. 


\section{Hypothesis Development}

Two streams of research consider how firms mitigate the effects of financing constraints on investment. The first suggests that firms can reduce information asymmetry and financing constraints by committing to better accounting quality. The second finds that firms with larger financing constraints lease more of their assets. The joining of these two streams of research leads us to predict that firms with worse accounting quality are more likely to obtain their assets through operating leases. Our first hypothesis is:

H1: A firm's propensity to lease-versus-buy assets is declining in its accounting quality.

An alternative explanation for a negative association between a firm's accounting quality and their propensity to enter into operating leases is that firms with poor accounting quality prefer off-balance sheet financing. Under this alternative, we would expect the relationship between leasing and accounting quality to be unaffected by other mechanisms that reduce information asymmetry.

One mechanism that is likely to affect the extent of the firm's information asymmetry problem is whether the outside suppliers of capital, such as banks, have incentives to obtain information through private channels and thus reduce information asymmetry. If better accounting quality reduces information asymmetry and thus reduces a firm's leasing propensity, then other mechanisms that reduce information asymmetry like the lenders' incentives to access private information and monitor the borrower are likely to affect the importance of accounting quality on the lease-versus-buy decision.

Thus, our second hypothesis is: 
H2: The importance of accounting quality in the lease-versus-buy decision decreases with banks' incentives to perform due diligence.

Capital expenditure covenants are another mechanism that lenders use to reduce agency costs. ${ }^{14}$ If these covenants are effective at reducing agency costs and financing constraints, then the importance of accounting quality in the lease-versus-buy decision will also be reduced by capital expenditure covenants. In other words, accounting quality affects the lease-versus-buy decision (i.e., low-quality accounting limits or makes it more costly for firms to engage in capital spending so they turn to leasing). However, capital expenditure covenants, by their very nature, also limit the ability of firms to engage in capital spending. Therefore, when a covenant is already in place, the incremental impact of accounting quality on the lease-versus-buy decision is reduced. For example, a firm with a covenant in place may have to opt for leasing, even though it has high-quality accounting. ${ }^{15}$

Similar to our monitoring hypothesis, the negative association between a firm's accounting quality and their propensity to enter into operating leases could be due to firms with poor accounting quality preferring off-balance sheet financing. Under this alternative hypothesis, we would expect the relationship between leasing and accounting quality to be unaffected by the use of capital investment restrictions.

Thus, our third hypothesis is:

\footnotetext{
${ }^{14} \mathrm{We}$ focus on this covenant and not on other financial covenants for two reasons. First, this covenant restricts asset purchases, impacting the decision to lease vs. buy, which is the focus of our study. Second, this covenant is not based on any financial ratios or earnings numbers, so it is unaffected by the method of accounting for operating leases.

${ }^{15}$ This argument might lead to the question of why this covenant is in place for a firm with high-accounting quality. In our investment covenant model reported in Table 7 we document that in addition to accounting quality there are many other important determinants of these covenants. Because of these other important determinants, high accounting quality firms could still have covenants.
} 
H3: The importance of accounting quality in the lease-versus-buy decision is lower in the presence of capital expenditure restriction provisions

\section{SAMPLE SELECTION}

We use three different samples to test our hypotheses. The first is a comprehensive sample of manufacturing firms included on COMPUSTAT. Our second and third samples are sub-samples of the first sample. The first sub-sample is restricted to firms with data on lead lenders contained on the LPC database. The second sub-sample requires data on capital expenditure covenants on the SDC database.

\section{Comprehensive Sample}

We test our first hypothesis on the role of accounting quality in the leasing decision using a comprehensive sample of COMPUSTAT manufacturing firms. We identified 3,033 firms in SIC codes (2000-3999) during the period 1995-2006 with the data necessary to measure the variables we use to test our hypotheses.

\section{Sub-Samples with Lead Lender and Capital Expenditure Covenant Data}

We use a sub-sample of firms that borrow in the syndicated loan market to probe the cross-sectional variation in the effect of accounting quality on leasing activities and to ensure our results are not an artifact of a desire for off-balance-sheet accounting. We focus on the syndicated loan market for two reasons. First, the variation in bank loan ownership provides cross-sectional variation in lenders' private information and monitoring incentives. As we discuss above, the syndicate structure provides loan owners varying incentives to incur costs to collect private information and to monitor 
management (Sufi, 2007). Therefore, lead arrangers' ownership is an established proxy for the private information acquired and the quality of monitoring imposed by banks.

The second reason we focus on this market rests on the use of debt covenants in this market. Since private lenders have informational and monitoring advantage over public debt holders in writing and enforcing debt covenants that mitigate the agency problems of debt (e.g., Fama, 1985 and Diamond, 1984), bank loans provide crosssectional variation in the use of debt covenants that is rare in corporate bonds. We exploit the variation of the use of the covenant restricting capital expenditures to investigate the effect of direct monitoring by banks on the lease-versus-buy decision.

To test the relation between accounting quality and banks' private information and monitoring quality, we use a sample of 997 manufacturing firms that are covered by the LPC database and have loan ownership data. Consistent with prior research, to test our third hypothesis we use a sample of firms listed in the SDC syndicated loan database to identify firms that have investment restriction covenants. We identified 865 firms that are listed in the SDC database.

\section{RESEARCH DESIGN AND PROXIES}

The basic model that we use to test all three of our hypotheses is the same, although the samples studied and the estimation techniques used to estimate the models differ across our tests. To test our hypotheses, we estimate the following model:

Lease $=\beta_{0}+\beta_{1} * A c c Q u a l+\beta_{2} * N o d i v+\beta_{3} *$ Unrated $+\beta_{4} *$ Rating $+\beta_{5} *$ Size $+\beta_{6} *$ Loss + $\beta_{7}^{*} M T R+\varepsilon^{16}$

\section{Variable Definitions:}

\footnotetext{
${ }^{16}$ Throughout the paper all t-statistics are based on standard errors clustered at the 3-digit industry level.
} 
Lease: the average of the capitalized lease expenditure (lagged COMPUSTAT \#96 multiplied by 10) over the sum of PP\&E and capitalized lease expenditure (COMPUSTAT \#8+ lagged COMPUSTAT \#96 multiplied by 10).

AccQual: the first principal component of three accrual-based accounting quality metrics based on Bharath et al. (2008) (described in Appendix A).

Nodiv: An indicator variable equal to one if the firm never pays dividend (COMPUSTAT \#21) during the sample period, and zero otherwise.

Unrated: An indicator variable equal to one if the firm is never rated by the S\&P (COMPUSTAT \#280) during the sample period, and zero otherwise.

Rating: the average of S\&P ratings when the firm is rated by the S\&P. Following Sharpe and Nguyen (1995), the rating is coded 1 if the S\&P rating is between $\mathrm{AAA}$ and $\mathrm{A}-, 2$ if the rating is between $\mathrm{A}+$ and $\mathrm{A}-, 3$ if the rating is between $\mathrm{BBB}+$ and $\mathrm{BBB}-$, and 4 if the rating is between $\mathrm{BB}+$ and $\mathrm{D}$.

Size: the decile ranking of average of the natural log of sales (COMPUSTAT \#12). Loss: the average of the indicator variable for loss year, where the indicator variable equals one when the COMPUSTAT \#123 is less than zero.

MTR: the average of the marginal tax rates, based on John Graham's simulation technique, as reported on his website. ${ }^{17}$

We capitalize the minimum lease payment assuming a cost of capital of 10 percent and that the lease payments are a perpetuity. ${ }^{18}$ As such, the measure will be unaffected by the differences in accounting treatment for these two investment strategies. ${ }^{19}$

Following Bharath et al. (2008), we use accruals-based metrics to measure accounting quality (AccQual). They identify three common measures of accounting quality based on the work of Teoh et al. (1998), Dechow et al. (1995), and Dechow and Dichev (2002). They use a principal component analysis to isolate the common component of these three firm-level accounting quality proxies. Appendix A includes a description of our implementation of the Bharath et al. (2008) measure. Our definition of

\footnotetext{
${ }^{17}$ To see a summary of the approach he uses to obtain marginal tax rates, and request access to the underlying data please visit the following website: http://faculty.fuqua.duke.edu/ jgraham/

${ }^{18}$ While parsimonious, we recognize that this approach has drawbacks because the exact discount rate and payment timing is not known. To address these concerns, we also construct the variable discounting all future lease payments disclosed in the lease footnotes (5 years of payments and the thereafter piece), and varying the discount rate (between 8 and 12 percent)) and the results of our main tests are consistent with those reported. Thus our capitalization assumptions do not appear to be driving our results.

${ }^{19}$ In our paper, leases represent operating leases and therefore we use COMPUSTAT \#96 to measure lease activities should be appropriate. Since capital leases are classified as borrow-and-buy in this paper and since COMPUSTAT \#8 includes capital lease expenditures, our choice of this variable should be comprehensive.
} 
variables differs from theirs slightly because we modify the deflator used in constructing these variables to accommodate differences in accounting for operating leases versus asset purchase. The total asset deflator used in prior research would be affected by the off-balance sheet accounting treatment for operating leases. Instead, we use the sum of PP\&E and capitalized minimum lease payment, which is the same deflator used in calculating our dependent variable (see Christie, 1991, for a discussion of the advantages of this approach. $)^{20}$

The lease versus buy decision is likely to be affected by a variety of other factors (see Smith and Wakeman, 1985, for a summary). Taxes are one of the primary motivations for leasing. Firms that are not paying taxes (or have low marginal tax rates) prefer to lease as opposed to buy, as leasing allows firms in a higher tax bracket to take more advantage of the depreciation deduction.

Leasing is also likely to be related to whether the firm faces financing constraints. Following Sharpe and Nguyen (1995) and Eisfeldt and Rampini (2008), we include three variables to capture the financing constraints: Nodiv, Unrated and Rating. Non-dividendpaying firms are expected to have more financing constraints and therefore are more likely to lease. Unrated firms are also expected to have higher leasing propensity. We expect that worse rated firms have greater difficulties in raising capital, so this variable should be positively correlated with Lease.

We also include Size and Loss as control variables. Larger firms are likely to be less financially constrained and therefore Size is expected to have a negative coefficient.

\footnotetext{
${ }^{20}$ We also use total assets, total assets excluding Property, Plant and Equipment (COMPUSTAT \#8) and sales (COMPUSTAT \#12) as deflators, the results in the main analysis continue to hold.
} 
Finally, we assume loss firms have a lower marginal tax rate and are thus unable to take full advantage of the tax benefits of ownership of equipment. Therefore, we expect Loss to be positively correlated with lease activity.

It is important to note that we average all variables across the sample period thereby treating each firm as one observation rather than using panel data. There are several justifications for this research design choice. First, our primary variable of interest is a stock measure of the leasing propensity. This measure, as well as our financial reporting quality measure, is highly correlated through time. Including one observation per firm year, would introduce serial correlation in both our dependent and independent variable. Averaging our variables reduces the independence problems that arise from the serial correlation. Although this approach only captures the between-firm effect, it eliminates within firm correlation issues. We investigate the sensitivity of our results to this research design choice using a variety of analyses that are discussed in depth in the sensitivity analysis section. In particular, we replace the stock measure of leasing with a flow measure, and replace our accounting quality measure, with a measure using three years of data prior to the leasing decision, and find similar results.

\section{Comprehensive Sample}

To test our first hypothesis, we estimate equation (1) using OLS estimation for our comprehensive COMPUSTAT sample of manufacturing firms averaged over 19952006. If accounting quality and leasing are two alternative mechanisms for dealing with financing constraints then we expect better accounting quality to be associated with a lower propensity to lease, i.e., $\boldsymbol{\beta}_{1}$ to be negative. 


\section{Analysis of Due Diligence Efforts}

To test our second hypothesis, we follow Bharath et al. (2008) and estimate an endogenous switching model (Lee, 1978) for our sub-sample of 997 manufacturing firms that are covered by the LPC database and have loan ownership data. The endogenous switching model allows us to control for the endogeneity of the choice by syndicate participants to require the lead arrangers to hold a larger ownership position in the loan to enhance their due diligence and monitoring efforts when the borrower has more serious information asymmetries and higher credit risk (Sufi, 2007).

More specifically, the endogenous switching model has a "selection" equation modeling the syndication's decision to require lead lenders to hold a significant ownership position and two-second stage "regime" equations modeling the determinants of the firm's leasing propensity (one for firms where the lead lender holds a significant position, one for firms where the lead lender holds a relatively small amount of the loan).

The three regressions are estimated simultaneously using full information maximum likelihood. As discussed in Bharath et al. (2008), this approach controls for the selfselection associated with the decision by the syndicate to require the lead arranger to hold a relatively larger proportion of the loan and allows us to compare the effects of accounting quality on the firm's leasing propensity across the two "regimes". It also has the benefit of not requiring the coefficients on the determinants to lease to be the same across the two different regimes.

The selection model of the proportion of the loan held by the lead bank is a probit model as follows:

$$
\begin{aligned}
\text { Lead Rank } & =\beta_{0}+\beta_{1} * \text { AccQual }+\beta_{2} * \text { Nodiv }+\beta_{3} * \text { Unrated }+\beta_{4} * \text { Rating }+\beta_{5} * \text { Size } \\
& +\beta_{6} * \text { Loss }+\beta_{7} * \text { MTR }+\beta_{8} * \text { Loan }+\beta_{9} * \text { Maturity }+\varepsilon
\end{aligned}
$$


Most of the variables in equation (2) are also included in equation (1) and are defined above. To capture lead banks' incentives to acquire private information and monitor management we develop the measure Lead Rank. This variable is an indicator variable equal one if the average of the lead arrangers' ownership of the firm's bank loans exceeds the median of all sample firms, and zero otherwise. ${ }^{21} \mathrm{We}$ also include two exogenous variables, (exogenous in the sense that they are likely to be associated with the syndicate's decision to require the lead lender to hold a significant proportion of the loan, but not associated with the firm's leasing propensity). The first exogenous variable is the size of the deal (Loan) and the second exogenous variable is the maturity of the debt (Maturity).

We estimate two "regime" regressions, one for firms where the lead lender holds a relatively larger proportion of the loan, and one for the firms where the lead lender holds a relatively lower proportion of the loan. Both of the second stage regime regressions are maximum likelihood estimation of equation (1). If debt holder monitoring is a potential substitute for accounting quality in solving information problems, then, in the regime regressions, we expect the effect of accounting quality (AccQual) on the leasing propensity will be relatively larger for firms where the lead lender holds a relatively smaller proportion of the loan. To test this hypothesis, we conduct a chisquared test on the equality of the coefficient on accounting quality across the two regime regressions.

\footnotetext{
${ }^{21}$ Since firms may have more than one loan during the sample period, lead arranger ownership and other loan characteristics are weighted (by deal amount) and averaged over all bank loans issued during the sample period. Using equally weighted values does not change the tenor of the results. We examine the sensitivity of our results to the median cut-off in the robustness section.
} 


\section{Analysis of Capital Expenditure Covenant}

Similar to our tests of hypothesis 2, we again employ an endogenous switching model to test hypothesis 3 , which predicts that the effects of investment restrictions on the importance of accounting quality on the firm's leasing propensity. The selection model we employ in this analysis is as follows:

$$
\begin{gathered}
\text { Inv_Cov }=\beta_{0}+\beta_{1} * \text { AccQual }+\beta_{2} * \text { Nodiv }+\beta_{3} * \text { Unrated }+\beta_{4} * \text { Rating }+\beta_{5} * \text { Size }+ \\
\beta_{6} * \text { Loss }+\beta_{7} * M T R+\beta_{8} * \text { Loan }+\beta_{9} * \text { Maturity }+\varepsilon
\end{gathered}
$$

Most of the variables in equation (3) are also included in equation (1) and are defined above. Inv_Cov is an indicator variable that equals one if the firm ever includes a capital expenditure restriction provision in its bank loans during the sample period. The two "regime" regressions are the same as equation (1), except the partition is based on whether the firm's debt has an investment restriction (or not). If this covenant is useful in reducing the asset substitution or over-investment problem, then we expect the effect of accounting quality (AccQual) on the lease versus buy decision to be reduced in the presence of this restrictive covenant.

\section{EMPIRICAL RESULTS}

\section{Descriptive Statistics}

Table 1 provides descriptive statistics for our comprehensive sample partitioned into two groups: firms that are relatively more likely to lease assets (the high lease group) and firms that are less likely to lease assets (the low lease group). The partition is done based on the median lease propensity in the sample and, by construction; the high lease group has a higher leasing propensity than the low lease group. The high lease group also 
has lower accounting quality than the low lease group. They are also less likely to pay dividends, less likely to be rated, and if they are rated, they are likely to have a poor credit rating, suggesting that firms that lease are more likely to face financing constraints. Finally, firms with a higher propensity to lease have more losses, and have lower marginal tax rates.

Pearson correlations between our variables are reported in Table 2. The variables in this table are highly correlated, in a statistical sense, with p-value less than the $1 \%$ level. Consistent with Hypothesis 1, AccQual and Lease are negatively correlated. Also consistent with prior discussions, firms with financing constraints are more likely to lease than to purchase assets. In addition, Size and most variables (Nodiv, Unrated, Rating, and Loss) are highly correlated (over 50\%). Loss and $M T R$ are also highly correlated.

Table 3 reports descriptive statistics for the sub-sample of firms with syndicated loan data. In the second and third columns of Table 3, we partition the sample firms by the level of lead arranger ownership for the LPC sub-sample. Firms with better private information and monitoring quality, tend to be smaller, have worse accounting quality, and face more financial constraints. These firms are also characterized by a smaller debt size and shorter maturities. The fact that these firms have a greater propensity to lease is consistent with Sufi's (2007) finding that a high lead arranger ownership is associated with high information asymmetries and financing constraints. This observation suggests that it may be important to control for endogeneity before drawing any inferences.

The fourth and fifth columns in Table 3 partition the SDC sub-sample firms by whether the firm's bank loans contain the capital expenditure restriction. Firms that use 
this restrictive covenant tend to be smaller, lease less, face more financing constraints, and have lower performance. Also these firms have smaller loans with longer maturities.

\section{Multivariate Results}

Panel A of Table 4 provides the results of the OLS estimation of Equation (1) for the comprehensive sample of manufacturing firms. Consistent with our first hypothesis, we find that firms with worse accounting quality, i.e., low AccQual, have a greater propensity to lease assets. This result is both statistically and economically significant. For example, a standard deviation change in AccQual (standard deviation $=0.583$ ) is associated with a $7.1 \%$ change in the mean Lease $($ mean $=0.436){ }^{22}$

As for control variables, results on Nodiv, Unrated, Size, Loss and MTR are consistent with our predictions that firms with more financial constraints have a greater propensity to lease assets. For comparative purposes we repeat the analysis for the comprehensive sample on our lead lender sub-sample and report the results for this subsample in Panel B of Table 4. The results on both our test and control variables are quite similar across these two samples. This suggests that any differences between our comprehensive sample of COMPUSTAT manufacturing firms and the sub-sample of these firms with syndicated loans do not affect our lease-versus-buy findings.

We present the results on our tests of the effect of banks' due diligence incentives on the lease-versus-buy decision in Table 5. In the first column of results we report the determinants of the leasing propensity for firms where the lead lender holds a relatively larger proportion of the loan (i.e. Lead Rank = 1). In the second column of results we

\footnotetext{
${ }^{22}$ While not reported, we find that the VIF of our accounting quality measure is 1.25 , so our finding that financial reporting quality influences leasing activities is not driven by multi-collinearity.
} 
report the determinants of the leasing propensity for firms where the lead lender holds a relatively smaller proportion of the loan (i.e. Lead Rank =0).

Focusing on the determinants to lease for firms where the lead lender has a stronger incentive to monitor, we find that smaller firms, firms that suffered a loss, and firms that aren't paying dividends are more likely to lease. These results are consistent with the results in Eisfeldt and Rampini (2008) and Sharpe and Nguyen (1995) that firms that are more likely to have financing constraints have a greater propensity to lease. We also find that AccQual has a significant negative coefficient, indicating that worse accounting quality is associated with a greater leasing propensity for firms with a high lead arranger ownership in bank loans.

For firms where the lead lender has less monitoring incentives, we again find that AccQual has a significant negative coefficient, indicating that worse accounting quality is associated with a greater leasing propensity, but the magnitude of the coefficient is lower. We conduct a chi-squared test on the coefficient on accounting quality across these two regressions to test hypothesis 2 . We find that the coefficient on accounting quality is statistically larger for firms that have lenders with fewer monitoring incentives. Thus, when information asymmetry problems are likely to be larger, accounting quality plays a relatively more important role in the leasing decision.

We report the results of our tests of hypothesis 3 on the effects of direct monitoring via the capital expenditure covenant on the leasing propensity in Table 6 . The first column reports the results on the determinants of the leasing propensity for firms with investment restriction covenants. The second results column reports the determinants of the leasing propensity for firms without investment restriction covenants. 
We find that for the subset of firms with investment covenants, the firms that are unrated, or are rated and have relatively poor ratings have a greater propensity to lease assets. Similarly, for the subset of firms without investment covenants, we find that smaller firms and firms that have suffered losses have a greater propensity to lease assets. Similar to the results discussed above, these findings support the findings in Eisfeldt and Rampini (2008) and Sharpe and Nguyen (1995) that firms that are more likely to have financing constraints are more likely to lease.

We find that accounting quality is an important determinant of the lease-versus-buy decision for firms without investment covenants, and is not a significant determinant of the leasing propensity for firms with these covenants. A chi-squared test confirms that the effect of accounting quality on the leasing propensity is significantly different across these two regressions. These results support our hypothesis that accounting quality is relatively less important in leasing decisions when other mechanisms limit capital spending. Capital expenditure covenants, by their very nature, also limit the ability of firms to engage in capital spending. Therefore, when a covenant is already in place, the incremental impact of accounting quality on the lease-versus-buy decision is reduced. For example, a firm with a covenant in place may have to opt for leasing, even though it has high-quality accounting.

For completeness, we report the results of our "selection" regressions in Table 7. Although we do not develop hypotheses about the determinants of lead arranger's monitoring incentives or of investment covenants, we do find that many of the explanatory variables included in the models are statistically significant. Of particular importance are the coefficients on the variables that serve as exogenous instruments. We 
find that large lead arranger ownership decreases with loan amounts and maturities, while capital expenditure provisions increases with loan amount and maturities.

\section{Robustness Checks}

\section{Industry Composition}

We focus on the manufacturing industry to avoid the heterogeneity in financing, leasing and financial reporting choices across various industries. Untabulated results show that our findings continue to hold in analyses that include all industries and control for fixed industry effects.

\section{Lease Measure}

The main tabulated results are based on an approach that averages all variables across the sample period, where Lease is a stock measure. To show our results are not driven by this specific design, we also conduct a panel data analysis, where we measure accounting quality by averaging the absolute value of discretionary accruals over the three years prior to the measurement year of our leasing propensity variable.

We also define Lease using a flow measure, consistent with Sharpe and Nguyen (1995) and Eisfeldt and Rampini (2008). The flow measurement of Lease is defined as minimum lease payment (lagged COMPUSTAT \#96) divided by the sum of lease and capital expenditures (COMPUSTAT \#128). Table 8 shows that panel data analysis generates results consistent with our main approach, firms with higher accounting quality are less likely to lease than to buy.

To verify the negative association between leasing and accounting quality we replace the scalar in our model with the sum of total assets and capitalized lease 
obligations (COMPUSTAT \# 6 + lagged COMPUSTAT \#96 multiplied by 10). We continue to observe a significantly negative association between accounting quality and leasing indicating that firms with lower accounting quality lease more. Finally, Tobit estimation including firms with missing lease data (about $8 \%$ of firms) produces similar results.

\section{Accounting Quality Measure}

In addition to using the principle component approach to measuring accruals quality, we also derive measures based on the underlying variables, and include those measures in the model. Our results continue to hold when we use these underlying variables. To ensure the decision to use cross-sectional estimation is not affecting our results, we also use a time series measure of the extent of current accruals mapping into future, current, and future operating cash flows (Dechow and Dichev, 2002) as a metric for accounting quality. The results of using this time-series measure are consistent with the results of using cross-sectional models.

Similarly, we change the scalar used in the accounting quality measures to be consistent with the scalar used on the independent variable, and to ensure that differences in the accounting treatment for leases is not driving our results. If we use total assets as the scalar, we find results similar to those that we tabulate in the paper.

\section{Lead Rank Measure}

Consistent with Sufi's (2007) findings, using a Herfindahl index of bank loan ownership in our lead rank proxy produces consistent results. 
To test the sensitivity of our results to our choice of above version below the median lead ownership in defining our lead rank measure we examined two alternative cut-offs. Setting this variable equal one if the average of the lead arrangers' ownership of the firm's bank loans exceeds the $66^{\text {th }}$ percentile of all sample firms, and zero otherwise produces similar results. Similarly, setting this variable equal one if the average of the lead arrangers' ownership of the firm's bank loans exceeds the $33^{\text {th }}$ percentile of all sample firms, and zero otherwise produces similar results. The results of these alternative specifications suggest that our results are not driven by our median cut-off. ${ }^{23}$

\section{Financial Constraints}

Finally, when the firm has lower free cash flow information problems are more likely to affect investment efficiency through their effect on external financing. We interact accounting quality proxies with a dummy variable for high free cash flow. We find that the importance of accounting quality affecting leasing activities decreases with free cash flow, consistent with our prediction.

\section{CONCLUSION}

This paper extends prior research on the relation between financial reporting quality and firms' investment and financing choices by investigating the effect of financial reporting quality on the lease-versus-buy decision. Our research design complements prior studies that focus exclusively on asset purchases when examining the effect of accounting quality on firm's investment decisions. We find that the leasing

\footnotetext{
${ }^{23}$ We also tried a different specification where we interact continuous lead ownership with our accounting quality measure. The magnitude of the coefficient on AccQual decreases with lead ownership, consistent with the dichotomization approach.
} 
propensity is declining in accounting quality. This finding suggests that although previous research shows that firms with poor accounting quality buy fewer assets, they lease more of their assets indicating that poor accounting quality may not result in lower total investment.

To distinguish between two alternative explanations of this finding, we also examine the mechanisms lenders use to mitigate the agency problems arising from information asymmetries. Only if better accounting quality and leasing are two alternative mechanisms for addressing financial constraints would we expect the negative relation between accounting quality and leasing to be mitigated by other mechanism that reduce information asymmetry and agency costs. We find that accounting information is less important in the decision to lease when lenders' incentives to conduct due diligence are higher. The importance of financial reporting quality in the lease-versus-buy decision is also decreasing in the existence of capital expenditure covenants. Although the relation between leasing and accounting quality might be indicative of a propensity of firms with otherwise poor accounting quality to engage in off-balance sheet financing, our results are more consistent with accounting quality and leasing serving as substitute mechanisms for reducing financing constraints.

Our findings suggest that ignoring the use of off-balance sheet leasing as a substitute for asset purchases is likely to affect the inferences about the effect of accounting quality on firm investment that can be drawn from the association between measures of information asymmetry, accounting quality, and asset purchases. Our analyses also contribute to the literature examining the importance of accounting information in firms' investment 
decisions by considering how banks' private information and monitoring can substitute for accounting information. 


\section{References}

Ball, R., R. Bushman, and F. Vasvari, 2007. The Debt-Contracting Value of Accounting Information and Loan Syndicate Structure. University of North Carolina, Working Paper.

Bharath T., J. Sunder, and S. Sunder, 2008. Accounting Quality and Debt Contracting. The Accounting Review, 1-28.

Biddle, G., and G. Hilary, 2006. Accounting Quality and Firm-Level Capital Investment. The Accounting Review 81, 963-982.

Biddle, G., G. Hilary, and R. Verdi. 2009. How Does Financial Reporting Quality Improve Investment Efficiency? - Working Paper - MIT.

Bushman, R., J. Piotroski, and A. Smith, 2005. Capital Allocation and Timely Accounting Recognition of Economic Losses: International Evidence, University of Chicago, Working Paper.

Bushman, R., A, Smith, and F. Zhang, 2007. Investment-Cash Flow Sensitivities are Really Investment-Investment Sensitivities. University of North Carolina, Working Paper.

Dechow, P., and I. Dichev, 2002. The Quality of Accruals and Earnings: The Role of Accrual Estimation Errors. The Accounting Review 77, 35-59.

Dechow, P., R. Sloan, and A. Sweeney, 1995. Detecting Earnings Management. The Accounting Review 70, 193-225

Diamond, D., 1984. Financial Intermediation and Delegated Monitoring. Review of Economic Studies 51, 393-414.

Eisfeldt, L., and A. Rampini, 2008 Leasing, Ability to Repossess, and Debt Capacity, Review of Financial Studies

Fama, E. F., 1985. What's Different about Banks? Journal of Monetary Economics 15, 29-36.

Fazzari, S., R.G. Hubbard, and B. Petersen, 1988. Investment and Finance Reconsidered. Brookings Papers on Economic Activity, 141-195.

Holthausen, R., and R. Verrecchia, 1998. The Effect of Sequential Information Release on the Variation of Price Changes in an Intertemporal Multi-asset Market. Journal of Accounting Research 26, 82-106.

Hope, O.K., W. Thomas, and D. Vyas. 2008. Transparency, Ownership, and Financing Constraints: An International Study Using Private Firms. Working Paper University of Toronto. 
Graham, John R., Michael Lemmon, and James Schallheim, 1998, Debt, Leases, Taxes, and the Endogeneity of Corporate Tax Status. Journal of Finance 53, 131-162.

Jensen, M., and W. Meckling, 1976. Theory of the Firm: Managerial Behavior, Agency Costs, and Ownership Structure. Journal of Financial Economics 3, 305-360.

Kaplan, S. N., and L. Zingales, 1997. Do Investment-Cash Flow Sensitivities Provide Useful measures of Financing Constraints? Quarterly Journal of Economics 112, 169-215.

Kaplan, S. N., and L. Zingales, 2000. Investment-Cash Flow Sensitivities Are Not Valid measures of Financing Constraints. Quarterly Journal of Economics 115, 707-712.

Lee, L., 1978, Unionism and Wage Rates: A Simultaneous Equations Model with Qualitative and Limited Dependent Variables. International Economic Review, 19, 415-434.

Lara, J.M., B. G. Osma, and F. Penalva. 2009 Conditional Conservatism and Firm Investment Efficiency. Working Paper - Universidad Carlos III de Madrid

Nini, G., D. Smith and A. Sufi, 2006. Creditor Control Rights and Firm Investment Policy. Board of Governors of the Federal Reserve System, Working Paper.

Sharpe, S., and H. Nguyen, 1995. Capital Market Imperfections and the Incentive to Lease. Journal of Financial Economics 39, 271-294.

Smith, C., and M. Wakeman, 1985. Determinants of Corporate Leasing Policy. Journal of Finance 40, 895-908

Sufi, A., 2007. Information Asymmetry and Financing Arrangements: Evidence from Syndicated Loans. Journal of Finance 62, 629-668.

Teoh, S. H., I. Welch, and T. J. Wong, 1998. Earnings Management and the Underperformance of Seasoned Equity Offerings. Journal of Financial Economics 50, 63-99.

Verdi, R., 2006. Financial Reporting Quality and Investment Efficiency. MIT, Working Paper. 


\section{APPENDIX A}

\section{Construction of AccQual}

ABACC1: the absolute value of current discretionary accruals calculated based on Teoh et al. (1998). The model is estimated annually for each Fama/French (1997) industry group and each industry-year regression requires at least 20 observations. Based on Teoh et al. (1998) we first estimate the following regression to get the estimated coefficients (variables are defined below).

$$
\frac{\text { Current_Accc }}{\text { Total_Inv }}=\gamma_{1} \frac{1}{\text { Total_Inv }}+\gamma_{2} \frac{\Delta \operatorname{Re} v}{\text { Total_Inv }}+\eta
$$

The second step calculates the absolute value of discretionary accruals as:

$$
\left|\frac{\text { Current_Acc }}{\text { Total_Inv }}-\hat{\gamma}_{1} \frac{1}{\text { Total_Inv }}-\hat{\gamma}_{2} \frac{(\Delta \operatorname{Re} v-\Delta A R)}{\text { Total_Inv }}\right|
$$

ABACC2: the absolute value of total discretionary accruals calculated based on Dechow et al. (1995). The model is estimated annually for each Fama/French (1997) industry group and each industry-year regression requires at least 20 observations. We first estimate the following regression to get the estimated coefficients (variables are defined below).

$$
\frac{\text { Total_Acc }}{\text { Total_Inv }}=\alpha_{1} \frac{1}{\text { Total_Inv }}+\alpha_{2} \frac{\Delta \operatorname{Re} v}{\text { Total_Inv }}+\alpha_{3} \frac{P P E}{\text { Total_Inv }}+\varepsilon
$$

The second step calculates the absolute value of discretionary accruals as:

$$
\left|\frac{\text { Total_Acc }}{\text { Total_Inv }}-\hat{\alpha}_{1} \frac{1}{\text { Total_Inv }}-\hat{\alpha}_{2} \frac{(\Delta \operatorname{Re} v-\Delta A R)}{\text { Total_Inv }}-\hat{\alpha}_{3} \frac{P P E}{\text { Total_Inv }}\right|
$$

ABACC3: the absolute value of total current accruals calculated based on Dechow and Dichev (2002). The model is estimated annually for each Fama/French (1997) industry group and each industry-year regression requires at least 20 observations. ABACC 3 is the absolute value of the estimated residual from the following model.

$$
\frac{\text { Current_Acc }}{\text { Total_Inv }}=\theta_{0}+\theta_{1}\left(\frac{C F O}{\text { Total_Inv }}\right)_{t-1}+\theta_{2}\left(\frac{C F O}{\text { Total_Inv }}\right)_{t}+\theta_{3}\left(\frac{C F O}{\text { Total_Inv }}\right)_{t+1}+v
$$

where 
Current_Acc $=$ Earnings before extraordinary items - Cash flow from operating activities - Depreciation (COMPUSTAT \#123 - \#308 + \#14); ${ }^{24}$

Total_Acc = Earnings before extraordinary items - Cash flow from operating activities (COMPUSTAT \#123 - \#308);

Total_Inv = the sum of PP\&E and capitalized lease expenditure (COMPUSTAT \#8+ lagged COMPUSTAT \#96 multiplied by 10);

CFO = Cash flow from operating activities (COMPUSTAT \#308);

$\Delta \operatorname{Rev} \quad=$ Change in sales (COMPUTSTAT \#12);

$\Delta \mathbf{A R}=$ Change in accounts receivables (COMPUSTAT \#2).

PPE = property, plant and equipment (COMPUSTAT \#8).

We standardize each of the three measures by subtracting the mean and dividing by the standard deviation, and then extract the first principal component from the three proxies. ${ }^{25}$ Our accounting quality variable (AccQual) is thus defined as the average of the following metric over the sample period 1995-2006:

$-1 *[$ standardizedABACC1 $* 0.38538+$ standardizedABACC2 $* 0.38371+$ standardized ABACC3 $* 0.32568]^{26}$

\footnotetext{
${ }^{24}$ In robustness checks, we adjust the current accruals by excluding change in prepaid rental expenses to accommodate differences in accounting for operating leases vs. asset purchase, and this adjustment does not affect the results.

${ }^{25}$ The first principal component explains on average about 80 percent of the corresponding cross-sectional sample variance and only the first Eigen value is greater than one. We therefore conclude that the first principal component captures most of the common variation among the three proxies.

${ }^{26}$ We multiply by negative one to make the metric higher for firms with better accounting quality. The Pearson correlations between the first principal component and the three accounting quality proxies are very high, ranging from $-80 \%$ to $-95 \%$.
} 


\section{TABLE 1}

\section{Descriptive statistics (means and medians) for sample firms partitioned by their leasing propensity for the period 1995-2006}

\begin{tabular}{|c|c|c|c|c|}
\hline & \multicolumn{2}{|c|}{ High Lease } & \multicolumn{2}{c|}{ Low Lease } \\
\hline & Mean & Median & $\begin{array}{c}\text { Mean } \\
\text { (t-stat for high lease - } \\
\text { low Lease) }\end{array}$ & $\begin{array}{c}\text { Median } \\
\text { (Wilcoxon z-stat for high } \\
\text { lease - low Lease) }\end{array}$ \\
\hline Lease & 0.650 & 0.652 & $\begin{array}{c}0.223 \\
(94.54)^{* * *}\end{array}$ & $\begin{array}{c}0.223 \\
(47.69)^{* * *}\end{array}$ \\
\hline AccQual & -0.147 & 0.079 & $\begin{array}{c}0.217 \\
(-18.11)^{* * *}\end{array}$ & $\begin{array}{c}0.348 \\
(-22.63)^{* * *}\end{array}$ \\
\hline Nodiv & 0.822 & 1.000 & $\begin{array}{c}0.464 \\
(22.15)^{* * *}\end{array}$ & $\begin{array}{c}0.000 \\
(20.55)^{* * *}\end{array}$ \\
\hline Unrated & 0.880 & 1.000 & $\begin{array}{c}0.584 \\
(19.50)^{* * *}\end{array}$ & $\begin{array}{c}3.000 \\
(18.38)^{* * *}\end{array}$ \\
\hline Rating+ & 3.604 & 4.000 & $\begin{array}{c}3.134 \\
(6.53)^{* * *}\end{array}$ & $\begin{array}{c}6.000 \\
(-25.06)^{* * * *}\end{array}$ \\
\hline Size & 3.194 & 3.000 & $\begin{array}{c}5.807 \\
(-28.14)^{* * *}\end{array}$ & $\begin{array}{c}0.200 \\
(23.23)^{* * *}\end{array}$ \\
\hline Loss & 0.580 & 0.600 & $\begin{array}{c}0.282 \\
(25.73)^{* * *}\end{array}$ & $\begin{array}{c}0.214 \\
(-20.20)^{* * *}\end{array}$ \\
\hline MTR & 0.108 & 0.054 & $\begin{array}{c}0.198 \\
(-20.58)^{* * *}\end{array}$ & 1,516 \\
\hline $\begin{array}{c}\text { Number of } \\
\text { observations }\end{array}$ & 1,517 & 1,517 & 1,516 & \\
\hline Note High & & & & \\
\hline
\end{tabular}

Note: High Lease (Low Lease) include firms with Lease above (below) the median.

$* * *, * *, *$ Significant at the $1 \%, 5 \%$ and $10 \%$ level, respectively.

$+\quad$ The mean (median) values of this variable only apply to firms rated by the S\&P.

Variable Definitions:

Lease: the average of the capitalized lease expenditure (lagged COMPUSTAT \#96 multiplied by 10) over the sum of PP\&E and capitalized lease expenditure (COMPUSTAT \#8+ lagged COMPUSTAT \#96 multiplied by 10) .

AccQual: the first principal component of three accrual-based accounting quality metrics based on Bharath et al. (2008) (described in Appendix A).

Nodiv: An indicator variable equal to one if the firm never pays dividend (COMPUSTAT \#21) during the sample period, and zero otherwise.

Unrated: An indicator variable equal to one if the firm is never rated by the S\&P (COMPUSTAT \#280) during the sample period, and zero otherwise.

Rating: the average of $\mathrm{S} \& \mathrm{P}$ ratings when the firm is rated by the S\&P. Following Sharpe and Nguyen (1995), the rating is coded 1 if the S\&P rating is between $\mathrm{AAA}$ and $\mathrm{A}-, 2$ if the rating is between $\mathrm{A}+$ and $\mathrm{A}-, 3$ if the rating is between $\mathrm{BBB}+$ and $\mathrm{BBB}-$, and 4 if the rating is between $\mathrm{BB}+$ and $\mathrm{D}$.

Size: the decile ranking of average of the natural log of sales (COMPUSTAT \#12). 
Loss: the average of the indicator variable for loss year, where the indicator variable equals one when the COMPUSTAT \#123 is less than zero.

MTR: the average of the marginal tax rates, based on John Graham's simulation technique. As reported on his website. 
TABLE 2

Pearson correlation coefficients (p-values) for lease model variables during the period 1995-2006

\begin{tabular}{|c|c|c|c|c|c|c|c|c|}
\hline Variables & Lease & AccQual & Nodiv & Unrated & Rating & Size & Loss & MTR \\
\hline Lease & 1 & $\begin{array}{c}-0.351 \\
(0.001)\end{array}$ & $\begin{array}{c}0.399 \\
(0.001)\end{array}$ & $\begin{array}{c}0.369 \\
(0.001)\end{array}$ & $\begin{array}{c}0.298 \\
(0.001)\end{array}$ & $\begin{array}{l}-0.532 \\
(0.001)\end{array}$ & $\begin{array}{c}0.471 \\
(0.001)\end{array}$ & $\begin{array}{l}-0.387 \\
(0.001)\end{array}$ \\
\hline AccQual & & 1 & $\begin{array}{c}-0.301 \\
(0.001)\end{array}$ & $\begin{array}{l}-0.233 \\
(0.001)\end{array}$ & $\begin{array}{l}-0.191 \\
(0.001)\end{array}$ & $\begin{array}{c}0.398 \\
(0.001)\end{array}$ & $\begin{array}{l}-0.398 \\
(0.001)\end{array}$ & $\begin{array}{c}0.318 \\
(0.001)\end{array}$ \\
\hline Nodiv & & & 1 & $\begin{array}{c}0.363 \\
(0.001)\end{array}$ & $\begin{array}{c}0.482 \\
(0.001)\end{array}$ & $\begin{array}{l}-0.552 \\
(0.001)\end{array}$ & $\begin{array}{c}0.501 \\
(0.001)\end{array}$ & $\begin{array}{l}-0.417 \\
(0.001)\end{array}$ \\
\hline Unrated & & & & 1 & N/A & $\begin{array}{l}-0.658 \\
(0.001)\end{array}$ & $\begin{array}{c}0.312 \\
(0.001)\end{array}$ & $\begin{array}{l}-0.192 \\
(0.001)\end{array}$ \\
\hline Rating & & & & & 1 & $\begin{array}{l}-0.568 \\
(0.001)\end{array}$ & $\begin{array}{c}0.495 \\
(0.001)\end{array}$ & $\begin{array}{l}-0.309 \\
(0.001)\end{array}$ \\
\hline Size & & & & & & 1 & $\begin{array}{l}-0.644 \\
(0.001)\end{array}$ & $\begin{array}{c}0.492 \\
(0.001)\end{array}$ \\
\hline Loss & & & & & & & 1 & $\begin{array}{l}-0.695 \\
(0.001)\end{array}$ \\
\hline MTR & & & & & & & & 1 \\
\hline
\end{tabular}

Note: Correlations with Rating only apply to firms that are rated by the S\&P.

Variable Definitions:

Lease: the average of the capitalized lease expenditure (lagged COMPUSTAT \#96 multiplied by 10) over the sum of PP\&E and capitalized lease expenditure (COMPUSTAT \#8+ lagged COMPUSTAT \#96 multiplied by 10) .

AccQual: the first principal component of three accrual-based accounting quality metrics based on Bharath et al. (2008) (described in Appendix A).

Nodiv: An indicator variable equal to one if the firm never pays dividend (COMPUSTAT \#21) during the sample period, and zero otherwise.

Unrated: An indicator variable equal to one if the firm is never rated by the S\&P (COMPUSTAT \#280) during the sample period, and zero otherwise.

Rating: the average of $\mathrm{S} \& \mathrm{P}$ ratings when the firm is rated by the S\&P. Following Sharpe and Nguyen (1995), the rating is coded 1 if the S\&P rating is between $A A A$ and $A-, 2$ if the rating is between $A+$ and $A-, 3$ if the rating is between $\mathrm{BBB}+$ and $\mathrm{BBB}-$, and 4 if the rating is between $\mathrm{BB}+$ and $\mathrm{D}$.

Size: the decile ranking of average of the natural log of sales (COMPUSTAT \#12).

Loss: the average of the indicator variable for loss year, where the indicator variable equals one when the COMPUSTAT \#123 is less than zero.

MTR: the average of the marginal tax rates, based on John Graham's simulation technique. As reported on his website. 


\section{TABLE 3}

Descriptive statistics (means) for sample firms partitioned on whether the firm uses a capital expenditure restriction in bank loans and the lead lenders' ownership of bank loans for the period 1995-2006

\begin{tabular}{|c|c|c|c|c|}
\hline & $\begin{array}{c}\text { High Lead } \\
\text { Arrangers' } \\
\text { Ownership }\end{array}$ & $\begin{array}{c}\text { Low Ownership (t- } \\
\text { stat for difference) }\end{array}$ & $\begin{array}{c}\text { With Capital } \\
\text { Expenditure } \\
\text { Restrictions }\end{array}$ & $\begin{array}{c}\text { Without } \\
\text { Restrictions (t-stat } \\
\text { for difference) }\end{array}$ \\
\hline Lease & 0.458 & $\begin{array}{c}0.316 \\
(10.58)^{* * *}\end{array}$ & 0.371 & $\begin{array}{c}0.325 \\
(3.40)^{* * *}\end{array}$ \\
\hline AccQual & 0.071 & $\begin{array}{c}0.302 \\
(-9.94)^{* * *}\end{array}$ & 0.223 & $\begin{array}{c}0.249 \\
(-1.02)\end{array}$ \\
\hline Nodiv & 0.728 & $\begin{array}{c}0.315 \\
(14.29)^{* * *}\end{array}$ & 0.556 & $\begin{array}{c}0.391 \\
(4.82)^{* * *}\end{array}$ \\
\hline Unrated & 0.888 & $\begin{array}{c}0.359 \\
(20.52)^{* * *}\end{array}$ & 0.497 & $\begin{array}{c}0.493 \\
(0.13)\end{array}$ \\
\hline Rating+ & 3.802 & $\begin{array}{c}3.097 \\
(6.19)^{* * *}\end{array}$ & 3.792 & $\begin{array}{c}3.002 \\
(12.17)^{* * *}\end{array}$ \\
\hline Size & 3.814 & $\begin{array}{c}7.424 \\
(-32.14)^{* * *}\end{array}$ & 6.158 & $\begin{array}{c}6.632 \\
(-3.75)^{* * *}\end{array}$ \\
\hline Loss & 0.423 & $\begin{array}{c}0.183 \\
(14.00)^{* * *}\end{array}$ & 0.319 & $\begin{array}{c}0.226 \\
(5.16)^{* * *}\end{array}$ \\
\hline MTR & 0.157 & $\begin{array}{c}0.213 \\
(-7.45)^{* * *}\end{array}$ & 0.208 \\
& & $\begin{array}{c}24.218 \\
(69.44)^{* * *}\end{array}$ & N/A & $\begin{array}{c}\text { N/A } \\
\text { (- }\end{array}$ \\
\hline Lead Own & 89.624 & $\begin{array}{c}19.433 \\
(-41.35)^{* * *}\end{array}$ & 18.091 & $\begin{array}{c}18.326 \\
(-2.13)^{* *}\end{array}$ \\
\hline Loan & 16.364 & $\begin{array}{c}3.869 \\
(-12.80)^{* * *}\end{array}$ & 3.770 & $\begin{array}{c}3.591 \\
(5.16)^{* * *}\end{array}$ \\
\hline Maturity & 3.367 & 498 & 374 & 491 \\
\hline $\begin{array}{c}\text { Number of } \\
\text { observations }\end{array}$ & 499 & & & \\
\hline
\end{tabular}

$* * *, * *, *$ Significant at the $1 \%, 5 \%$ and $10 \%$ level, respectively.

+ The mean values of this variable only apply to firms that are rated by the S\&P.

\section{Variable Definitions:}

Lease: the average of the capitalized lease expenditure (lagged COMPUSTAT \#96 multiplied by 10) over the sum of PP\&E and capitalized lease expenditure (COMPUSTAT \#8+ lagged COMPUSTAT \#96 multiplied by 10) .

AccQual: the first principal component of three accrual-based accounting quality metrics based on Bharath et al. (2008) (described in Appendix A).

Nodiv: An indicator variable equal to one if the firm never pays dividend (COMPUSTAT \#21) during the sample period, and zero otherwise. 
Unrated: An indicator variable equal to one if the firm is never rated by the S\&P (COMPUSTAT \#280) during the sample period, and zero otherwise.

Rating: the average of S\&P ratings when the firm is rated by the S\&P. Following Sharpe and Nguyen (1995), the rating is coded 1 if the S\&P rating is between AAA and A-, 2 if the rating is between A+ and A-, 3 if the rating is between $\mathrm{BBB}+$ and $\mathrm{BBB}-$, and 4 if the rating is between $\mathrm{BB}+$ and $\mathrm{D}$.

Size: the decile ranking of average of the natural log of sales (COMPUSTAT \#12).

Loss: the average of the indicator variable for loss year, where the indicator variable equals one when the COMPUSTAT \#123 is less than zero.

MTR: the average of the marginal tax rates , based on John Graham's simulation technique. As reported on his website.

Lead Own: The weighted average of the lead arrangers' ownership of the bank loan issued in the sample period.

Loan: The natural of log of the amount of bank loan issued in the sample period.

Maturity: The natural of log of the maturity (in months) of bank loan issued in the sample period. 
TABLE 4

Coefficients (and t-statistics) from OLS estimations of the determinants of the extent of firms' expenditures on operating leases

Panel A: Complete Sample

\begin{tabular}{|c|c|c|c|}
\hline Variables & Predicted Sign & Coefficients & t-stats \\
\hline Intercept & $+/-$ & 0.442 & $10.18^{* * *}$ \\
\hline AccQual & - & -0.053 & $-4.00^{* * *}$ \\
\hline Nodiv & + & 0.048 & $3.35^{* * *}$ \\
\hline Unrated & + & 0.057 & $1.67 *$ \\
\hline Rating & + & 0.003 & 0.34 \\
\hline Size & - & -0.022 & $-7.26^{* * *}$ \\
\hline Loss & + & 0.094 & $3.75^{* * *}$ \\
\hline MTR & - & -0.143 & $-2.88^{* * *}$ \\
\hline $\begin{array}{c}\text { Number of } \\
\text { observations }\end{array}$ & & 3,033 & \\
\hline R-Squared & & 0.3382 & \\
\hline
\end{tabular}

\section{Panel B: Syndicated Loan Sample}

\begin{tabular}{|c|c|c|c|}
\hline Variables & Predicted Sign & Coefficients & t-stats \\
\hline Intercept & $+/-$ & 0.467 & $7.37 * * *$ \\
\hline AccQual & - & -0.074 & $-3.32^{* * *}$ \\
\hline Nodiv & + & 0.036 & $2.21^{* *}$ \\
\hline Unrated & + & 0.028 & 0.73 \\
\hline Rating & + & 0.003 & 0.32 \\
\hline Size & - & -0.021 & $-4.32^{* * *}$ \\
\hline Loss & + & 0.085 & $2.66^{* * *}$ \\
\hline MTR & - & -0.102 & $-1.86^{*}$ \\
\hline $\begin{array}{c}\text { Number of } \\
\text { observations }\end{array}$ & & 1,314 & \\
\hline R-Squared & & 0.2414 & \\
\hline
\end{tabular}

Note: All t-statistics are based on clustering at the 3-digit industry level $* * *, * *, *$ Significant at the $1 \%, 5 \%$, and $10 \%$ levels respectively

\section{Variable Definitions:}

Lease: the average of the capitalized lease expenditure (lagged COMPUSTAT \#96 multiplied by 10) over the sum of PP\&E and capitalized lease expenditure (COMPUSTAT \#8+ lagged COMPUSTAT \#96 multiplied by 10) . 
AccQual: the first principal component of three accrual-based accounting quality metrics based on Bharath et al. (2008) (described in Appendix A).

Nodiv: An indicator variable equal to one if the firm never pays dividend (COMPUSTAT \#21) during the sample period, and zero otherwise.

Unrated: An indicator variable equal to one if the firm is never rated by the S\&P (COMPUSTAT \#280) during the sample period, and zero otherwise.

Rating: the average of S\&P ratings when the firm is rated by the S\&P. Following Sharpe and Nguyen (1995), the rating is coded 1 if the S\&P rating is between $\mathrm{AAA}$ and $\mathrm{A}-, 2$ if the rating is between $\mathrm{A}+$ and $\mathrm{A}-, 3$ if the rating is between $\mathrm{BBB}+$ and $\mathrm{BBB}-$, and 4 if the rating is between $\mathrm{BB}+$ and $\mathrm{D}$.

Size: the decile ranking of average of the natural log of sales (COMPUSTAT \#12).

Loss: the average of the indicator variable for loss year, where the indicator variable equals one when the COMPUSTAT \#123 is less than zero.

MTR: the average of the marginal tax rates, based on John Graham's simulation technique, as reported on his website. 
TABLE 5

Coefficients (and t-statistics) from endogenous switching models estimating how quality monitoring by banks, measured by lead lenders' ownership, affects the effect of accounting quality on lease expenditures

\begin{tabular}{|c|c|c|c|}
\hline & & Lead Rank $=1$ & Lead Rank $=0$ \\
\hline Variables & Predicted Sign & $\begin{array}{c}\text { Coefficients } \\
\text { (z-stats) }\end{array}$ & $\begin{array}{c}\text { Coefficients } \\
\text { (z-stats) }\end{array}$ \\
\hline Intercept & $+/-$ & $\begin{array}{c}0.455 \\
(1.75)^{*}\end{array}$ & $\begin{array}{c}0.402 \\
(4.78)^{* * *}\end{array}$ \\
\hline AccQual & - & $\begin{array}{c}-0.053 \\
(-2.22)^{* *}\end{array}$ & $\begin{array}{c}-0.211 \\
(-6.48) * * *\end{array}$ \\
\hline Nodiv & + & $\begin{array}{c}0.073 \\
(3.11)^{* * *}\end{array}$ & $\begin{array}{c}0.043 \\
(2.26)^{* *}\end{array}$ \\
\hline Unrated & + & $\begin{array}{l}0.044 \\
(0.17)\end{array}$ & $\begin{array}{l}0.063 \\
(1.29)\end{array}$ \\
\hline Rating & + & $\begin{array}{l}0.006 \\
(0.10)\end{array}$ & $\begin{array}{l}0.011 \\
(0.83)\end{array}$ \\
\hline Size & - & $\begin{array}{c}-0.020 \\
(-2.73) * * *\end{array}$ & $\begin{array}{l}-0.011 \\
(-1.45)\end{array}$ \\
\hline Loss & + & $\begin{array}{c}0.090 \\
(1.98)^{* *}\end{array}$ & $\begin{array}{l}0.053 \\
(1.24)\end{array}$ \\
\hline MTR & - & $\begin{array}{c}-0.253 \\
(-2.26)^{* *}\end{array}$ & $\begin{array}{l}-0.015 \\
(-0.21)\end{array}$ \\
\hline $\begin{array}{l}\text { Number of } \\
\text { observations }\end{array}$ & & 472 & 492 \\
\hline \multicolumn{4}{|c|}{$\begin{array}{l}\text { Differences in the impact of accounting quality on the lease vs. buy decision } \\
\qquad \begin{array}{c}\mathrm{H}_{0} \text { : AccQual } \\
(\text { Lead Rank }=1)=\text { AccQual }_{(\text {Lead Rank }=0)} \\
\chi^{2}(1)=15.42 \\
\mathrm{p} \text { value }=0.0001\end{array}\end{array}$} \\
\hline
\end{tabular}

Note: $* * *, * *, *$ Significant at the $1 \%, 5 \%$, and $10 \%$ levels, respectively

\section{Variable Definitions:}

Lead Rank: an indicator variable equal one if the average of the lead arrangers' ownership of the firm's bank loans exceeds the median of all sample firms, and zero otherwise

Lease: the average of the capitalized lease expenditure (lagged COMPUSTAT \#96 multiplied by 10) over the sum of PP\&E and capitalized lease expenditure (COMPUSTAT \#8+ lagged COMPUSTAT \#96 multiplied by 10) .

AccQual: the first principal component of three accrual-based accounting quality metrics based on Bharath et al. (2008) (described in Appendix A). 
Nodiv: An indicator variable equal to one if the firm never pays dividend (COMPUSTAT \#21) during the sample period, and zero otherwise.

Unrated: An indicator variable equal to one if the firm is never rated by the S\&P (COMPUSTAT \#280) during the sample period, and zero otherwise.

Rating: the average of S\&P ratings when the firm is rated by the S\&P. Following Sharpe and Nguyen (1995), the rating is coded 1 if the S\&P rating is between $\mathrm{AAA}$ and $\mathrm{A}-, 2$ if the rating is between $\mathrm{A}+$ and $\mathrm{A}-, 3$ if the rating is between $\mathrm{BBB}+$ and $\mathrm{BBB}-$, and 4 if the rating is between $\mathrm{BB}+$ and $\mathrm{D}$.

Size: the decile ranking of average of the natural log of sales (COMPUSTAT \#12).

Loss: the average of the indicator variable for loss year, where the indicator variable equals one when the COMPUSTAT \#123 is less than zero.

MTR: the average of the marginal tax rates based on John Graham's simulation technique, as reported on his website. 
TABLE 6

Coefficients (and t-statistics) from endogenous switching model estimation of the effect of capital expenditure restrictions on firms' leasing propensity

\begin{tabular}{|c|c|c|c|}
\hline & & Inv_Cov $=1$ & Inv_Cov $=0$ \\
\hline Variables & Predicted Sign & $\begin{array}{c}\text { Coefficients } \\
\text { (z-stats) }\end{array}$ & $\begin{array}{c}\text { Coefficients } \\
\text { (z-stats) }\end{array}$ \\
\hline Intercept & $+/-$ & $\begin{array}{c}-0.602 \\
(-2.66) * * *\end{array}$ & $\begin{array}{c}0.364 \\
(5.18) * * *\end{array}$ \\
\hline AccQual & - & $\begin{array}{l}-0.005 \\
(-0.15)\end{array}$ & $\begin{array}{c}-0.104 \\
(-4.51)^{* * *}\end{array}$ \\
\hline Nodiv & + & $\begin{array}{l}0.038 \\
(1.31)\end{array}$ & $\begin{array}{l}0.133 \\
(0.66)\end{array}$ \\
\hline Unrated & + & $\begin{array}{c}0.841 \\
(4.61)^{* * *}\end{array}$ & $\begin{array}{l}0.084 \\
(1.24)\end{array}$ \\
\hline Rating & + & $\begin{array}{c}0.234 \\
(4.77) * * *\end{array}$ & $\begin{array}{l}0.018 \\
(0.93)\end{array}$ \\
\hline Size & - & $\begin{array}{c}-0.018 \\
(-1.89)^{*}\end{array}$ & $\begin{array}{c}-0.013 \\
(-2.40)^{* *}\end{array}$ \\
\hline Loss & + & $\begin{array}{l}0.053 \\
(0.89)\end{array}$ & $\begin{array}{c}0.114 \\
(2.75)^{* * *}\end{array}$ \\
\hline MTR & - & $\begin{array}{l}-0.184 \\
(-1.38)\end{array}$ & $\begin{array}{l}-0.027 \\
(-0.35)\end{array}$ \\
\hline $\begin{array}{l}\text { Number of } \\
\text { observations }\end{array}$ & & 373 & 483 \\
\hline \multicolumn{4}{|c|}{$\begin{array}{l}\text { Differences in the impact of accounting quality on the lease vs. buy decision } \\
\mathrm{H}_{0} \text { : AccQual } \text { (Inv_Cov=1) }_{-}=\text {AccQual }_{(\text {Inv_Cov }=0)} \\
\chi^{2}(1)=5.66 \\
\mathrm{p} \text { value }=0.017\end{array}$} \\
\hline
\end{tabular}

Note: $* * *, * *, *$ Significant at the $1 \%, 5 \%$, and $10 \%$ levels, respectively

Variable Definitions:

Inv_Cov: is an indicator variable that equals one if the firm ever includes a capital expenditure restriction provision in its bank loans during the sample period.

Lease: the average of the capitalized lease expenditure (lagged COMPUSTAT \#96 multiplied by 10) over the sum of PP\&E and capitalized lease expenditure (COMPUSTAT \#8+ lagged COMPUSTAT \#96 multiplied by 10) .

AccQual: the first principal component of three accrual-based accounting quality metrics based on Bharath et al. (2008) (described in Appendix A).

Nodiv: An indicator variable equal to one if the firm never pays dividend (COMPUSTAT \#21) during the sample period, and zero otherwise.

Unrated: An indicator variable equal to one if the firm is never rated by the S\&P (COMPUSTAT \#280) during the sample period, and zero otherwise. 
Rating: the average of S\&P ratings when the firm is rated by the S\&P. Following Sharpe and Nguyen (1995), the rating is coded 1 if the S\&P rating is between $\mathrm{AAA}$ and $\mathrm{A}-, 2$ if the rating is between $\mathrm{A}+$ and $\mathrm{A}-, 3$ if the rating is between $\mathrm{BBB}+$ and $\mathrm{BBB}-$, and 4 if the rating is between $\mathrm{BB}+$ and $\mathrm{D}$.

Size: the decile ranking of average of the natural log of sales (COMPUSTAT \#12).

Loss: the average of the indicator variable for loss year, where the indicator variable equals one when the COMPUSTAT \#123 is less than zero.

MTR: the average of the marginal tax rates, based on John Graham's simulation technique, as reported on his website. 
TABLE 7

Coefficients (and z-statistics) from Probit models examining the determinants of the lead lenders' ownership and use of capital expenditure provisions for the period 1995-2006

\begin{tabular}{|c|c|c|c|}
\hline & Prediction & $\begin{array}{c}\text { Dependent variable: } \\
\text { Lead Rank } \\
\text { Coefficients } \\
\text { (z-stats) }\end{array}$ & $\begin{array}{c}\text { Dependent variable: } \\
\text { Inv_Cov } \\
\text { Coefficients } \\
\text { (z-stats) }\end{array}$ \\
\hline Variables & $+/-$ & 23.211 & -6.531 \\
$(10.98)^{* * *}$ & $(-5.82)^{* * *}$ \\
\hline Intercept & - & 0.055 & 0.104 \\
& & $(0.25)$ & $(0.82)$ \\
\hline AccQual & + & -0.041 & 0.077 \\
& & $(-0.27)$ & $(0.71)$ \\
\hline Nodiv & + & -1.228 & 3.396 \\
& & $(-1.73)^{*}$ & $(6.15)^{* * *}$ \\
\hline Unrated & + & -0.250 & 0.984 \\
& & $(-1.28)$ & $(6.52)^{* * *}$ \\
\hline Rating & - & -0.146 & -0.104 \\
& & $(-2.76)^{* * *}$ & $(-2.25)^{* *}$ \\
\hline Size & + & 0.391 & 0.486 \\
& & $(1.19)$ & $(2.35)^{* *}$ \\
\hline Loss & $+/-$ & 1.111 & 0.051 \\
& & $(1.96)^{* *}$ & $(0.11)$ \\
\hline MTR & $+/-$ & -1.132 & 0.010 \\
& & $(-10.81)^{* * *}$ & $(1.78)^{*}$ \\
\hline Loan & $+/-$ & -0.314 & 0.440 \\
& & $(-2.43)^{* *}$ & $(4.28)^{* * *}$ \\
\hline Maturity & & 964 & 856 \\
\hline Number of observations & & 0.6732 & 0.1442 \\
\hline Pseudo R-squared & & & \\
\hline
\end{tabular}

Note: All z-statistics are based on clustering at the 3-digit industry level.

$* * *, * *, *$ Significant at the $1 \%, 5 \%$, and $10 \%$ levels respectively

\section{Variable Definitions:}

Lead Rank: an indicator variable equal one if the average of the lead arrangers' ownership of the firm's bank loans exceeds the median of all sample firms, and zero otherwise

Inv_Cov: is an indicator variable that equals one if the firm ever includes a capital expenditure restriction provision in its bank loans during the sample period.

Lease: Measured as the average of the capitalized lease expenditure (lagged COMPUSTAT \#96 multiplied by 10) over the sum of PP\&E and capitalized lease expenditure (COMPUSTAT \#8+ lagged COMPUSTAT \#96 multiplied by 10) . 
AccQual: the first principal component of three accrual-based accounting quality metrics based on Bharath et al. (2008) (described in Appendix A).

Nodiv: An indicator variable equal to one if the firm never pays dividend (COMPUSTAT \#21) during the sample period, and zero otherwise.

Unrated: An indicator variable equal to one if the firm is never rated by the S\&P (COMPUSTAT \#280) during the sample period, and zero otherwise.

Rating: the average of S\&P ratings when the firm is rated by the S\&P. Following Sharpe and Nguyen (1995), the rating is coded 1 if the S\&P rating is between $\mathrm{AAA}$ and $\mathrm{A}-, 2$ if the rating is between $\mathrm{A}+$ and $\mathrm{A}-, 3$ if the rating is between $\mathrm{BBB}+$ and $\mathrm{BBB}-$, and 4 if the rating is between $\mathrm{BB}+$ and $\mathrm{D}$.

Size: the decile ranking of average of the natural log of sales (COMPUSTAT \#12).

Loss: the average of the indicator variable for loss year, where the indicator variable equals one when the COMPUSTAT \#123 is less than zero.

MTR: the average of the marginal tax rates, based on John Graham's simulation technique. As reported on his website.

Lead Own: The weighted average of the lead arrangers' ownership of the bank loan issued in the sample period.

Loan: The natural of log of the size of bank loan issued in the sample period.

Maturity: The natural of log of the maturity (in months) of bank loan issued in the sample period. 
TABLE 8

Coefficients (and t-statistics) from OLS estimations of the determinants of the extent of firms' expenditures on operating leases for the period 1995-2006 estimated using an annual regression and flow measures of lease proclivity

\begin{tabular}{|c|c|c|c|}
\hline Variables & Predicted Sign & Coefficients & t-stats \\
\hline Intercept & $+/-$ & 0.522 & $19.68^{* * *}$ \\
\hline AccQual & - & -0.042 & $-5.98^{* * *}$ \\
\hline Nodiv & + & 0.070 & $6.54 * * *$ \\
\hline Unrated & + & 0.056 & $2.27 * *$ \\
\hline Rating & + & 0.005 & 0.69 \\
\hline Size & - & -0.029 & $-14.69^{* * *}$ \\
\hline Loss & + & 0.030 & $4.14^{* * *}$ \\
\hline MTR & - & -0.135 & $-5.50^{* * *}$ \\
\hline $\begin{array}{c}\text { Number of } \\
\text { observations }\end{array}$ & & 15,055 & \\
\hline \begin{tabular}{c} 
R-Squared \\
\hline
\end{tabular} & & 0.3021 & \\
\hline
\end{tabular}

Note: All t-statistics are based on clustering at the firm level. Results on time fixed effects are omitted.

$* * *, * *, *$ Significant at the $1 \%, 5 \%$, and $10 \%$ levels respectively

\section{Variable Definitions:}

Lease: the lease expenditure (lagged COMPUSTAT \#96) over the sum of capital and lease expenditures (COMPUSTAT \#128+ lagged COMPUSTAT \#96) .

AccQual: the first principal component of three accrual-based accounting quality metrics based on Bharath et al. (2008) (described in Appendix A).

Nodiv: An indicator variable equal to one if the firm does not pay a dividend (COMPUSTAT \#21), and zero otherwise.

Unrated: An indicator variable equal to one if the firm is not rated by the $S \& P$ (COMPUSTAT \#280), and zero otherwise.

Rating: the average of S\&P ratings when the firm is rated by the S\&P. Following Sharpe and Nguyen (1995), the rating is coded 1 if the S\&P rating is between AAA and $\mathrm{A}_{-}, 2$ if the rating is between $\mathrm{A}+$ and $\mathrm{A}-, 3$ if the rating is between $\mathrm{BBB}+$ and $\mathrm{BBB}-$, and 4 if the rating is between $\mathrm{BB}+$ and $\mathrm{D}$.

Size: the decile ranking of average of the natural log of sales (COMPUSTAT \#12).

Loss: an indicator variable for loss year, where the indicator variable equals one when the COMPUSTAT \#123 is less than zero.

MTR: the marginal tax rates based on John Graham's simulation technique, as reported on his website. 